\title{
IMPLIKACJE TEORII PRAKTYK SPOLECZNYCH, PERSPEKTYWY WIELOPOZIOMOWEJ I PODEJŚCIA BEHAWIORALNEGO DLA BADAŃ UŻYTECZNYCH W POLITYCE KLIMATYCZNEJ ${ }^{1}$
}

\section{Streszczenie}

Współczesny dyskurs polityczny i naukowy nad polityką klimatyczną jest w dużej mierze zdominowany przez nauki przyrodnicze, techniczne oraz ekonomię neoklasyczną, a w mniejszej mierze psychologiczne podejście behawioralne. Prowadzi to do znaczącej luki poznawczej, którą starają się wypełnić podejścia bardziej socjologiczne, jak m.in. teoria praktyk społecznych i perspektywa wielopoziomowa. W niniejszym artykule przedstawiam podstawowe założenia teorii praktyk społecznych, perspektywy wielopoziomowej i podejścia behawioralnego, jak również proponuję sposób na jednoczesne wykorzystanie tych perspektyw w badaniach nad polityką klimatyczną. Przedstawiam także szereg przykładów badań empirycznych przeprowadzonych w ramach tych podejść badawczych oraz wskazuję na potencjalne kierunki przyszłych badań.

Słowa kluczowe: polityka klimatyczna, polityka energetyczna, socjologia środowiskowa, teoria praktyk społecznych, perspektywa wielopoziomowa, podejście behawioralne

* Wydział Prawa i Administracji; e-mail: andrzejsn44@gmail.com

1 Niniejszy tekst został napisany na podstawie wniosku o „Diamentowy Grant” na projekt obejmujący zastosowanie omawianych perspektyw badawczych w badaniach nad gminnymi politykami klimatycznymi. W związku z tym chciałbym serdecznie podziękować moim opiekunom naukowym - Piotrowi Matczakowi, za pomoc merytoryczną w przygotowaniu wniosku, jak również Dawidowi Sześcile, za pomoc w początkowych pracach nad wnioskiem. Dziękuję także anonimowym Recenzentom oraz członkom Redakcji za cenne uwagi i wskazówki. 


\section{WPROWADZENIE}

\section{Zagraniczne badania społeczne nad zmianami klimatu i politykami klimatycznymi}

Globalne zmiany klimatyczne wywoływane antropogeniczną emisją gazów cieplarnianych stanowią fundamentalny i niezwykle pilny problem dla społeczeństw i środowiska naturalnego Ziemi, nie wyłączając Polski. Wyrazem dostrzeżenia konieczności podjęcia działań przeciwdziałających (mitygujących) i adaptacyjnych do zmian klimatu są wciąż rozwijające się krajowe i międzynarodowe polityki klimatyczne. Wraz z działaniami władz publicznych również środowiska naukowe podejmują aktywny wysiłek nakierowany na dostarczanie wiedzy mającej praktyczne zastosowanie w politykach klimatycznych.

Badania nad współczesnymi zmianami klimatu rozpoczęły się w latach 60. ubiegłego wieku, natomiast ugruntowane zostały w latach 80., między innymi w związku z powołaniem w 1988 roku przez Program Środowiskowy Organizacji Narodów Zjednoczonych i Światową Organizację Meteorologiczną Międzyrządowego Panelu ds. Zmian Klimatu (IPCC) ${ }^{2}$, który podsumowuje aktualny stan badań w swoich raportach. Nauki społeczne miały jednak marginalne znaczenie w tym przedsięwzięciu, a ich perspektywy, szczególnie socjologii, nie zostały adekwatnie odzwierciedlone w raportach IPCC i innych agencji. Można to wiązać między innymi z tym, że same badania nad klimatem wywodzą się z obszaru nauk przyrodniczych, a badania socjologiczne nad tym tematem nabrały większego tempa na początku XXI wieku [Brulle, Dunlap 2015: 1-2].

Pomimo dynamicznego rozwoju badań społecznych nad zmianami klimatu po 2000 roku główne podejścia włączające je do głównego nurtu naukowego są krytykowane przez wielu naukowców, i nie tylko. Podejściu sustainability science zarzuca się to, że faktycznie podporządkowuje ono nauki społeczne perspektywom pochodzącym z nauk przyrodniczych, jak również to, że w centralnym miejscu umieszcza teorie systemów, często krytykowane w socjologii. Oba te zabiegi ograniczają zastosowanie unikalnych, społecznych perspektyw. Innym podejściom, które zdominowały udział nauk społecznych w nauce o klimacie, zarzuca się z kolei unikanie kontrowersyjnych tematów dotyczących uwikłania przyczyn zmian klimatycznych w konteksty polityczne i gospodarcze liberalnej gospodarki kapitalizmu konsumpcyjnego, i w relacje władzy, zbyt redukcjonistyczne i uproszczone wyjaśnianie ludzkich zachowań w przypadku ekonomii

2 Opis organizacji na jej oficjalnej stronie internetowej: http://www.ipcc.ch/organization/ organization.shtml [dostęp: 27.10.2018]. 
neoklasycznej oraz zbyt indywidualistyczne podejście w przypadku psychologii [Brulle, Dunlap 2015: 2-14].

Główny nurt badań nad zmianami klimatu i polityką klimatyczną jest więc zdominowany przez nauki przyrodnicze, techniczne i ekonomię neoklasyczną. Z innych nauk społecznych stosunkowo najsilniejszą pozycję wydaje się posiadać psychologia, głównie za sprawą tzw. podejścia behawioralnego do interwencji publicznych [Olejniczak, Śliwowski 2014]. Uznaje się jednak, że jej wkład stanowi jedynie częściowe wykorzystanie potencjału nauk społecznych, między innymi dlatego że, podobnie jak ekonomia neoklasyczna, przyjmuje ona głównie perspektywę indywidualistyczną [Shove 2010]. Wspomniane luki poznawcze wydaje się dobrze uzupełniać rozwijająca się żywiołowo socjologia zmian klimatu i badania nad zrównoważonymi przejściami (sustainable transitions), w tym takie nurty badawcze jak teoria praktyk społecznych [Shove, Pantzar, Watson 2012] i perspektywa wielopoziomowa [Geels 2002, 2011]. Same powody niskiego poziomu wykorzystania innych poza ekonomią nauk społecznych w politykach klimatycznych są jednak godne dalszych badań [Strzałkowski 2016: 465-467].

Jeżeli chodzi o konkretne ośrodki badawcze zajmujące się teorią praktyk społecznych i perspektywą wielopoziomowa, to można wspomnieć tu m.in. o DEMAND Centre na Uniwersytecie Lancaster [http://www.demand.ac.uk/], Centre on Innovation and Energy Demand na Uniwersytecie Sussex [http://www.cied.ac.uk], Sustainable Consumption Institute na Uniwersytecie Manchester [http://www.sci. manchester.ac.uk/], czy w przypadku zarządzania zrównoważonymi przejściami (transitions management) - the Dutch Research Institute for Transitions w Rotterdamie [https://drift.eur.nl/]. Warto również wspomnieć o dużym projekcie badawczym „Innovations in Climate Governance” [https://inogov.eu/], który jest inicjatywą naukową zajmującą się innowacjami w zarządzaniu klimatycznym.

\section{Polskie (i polsko-zagraniczne) badania społeczne nad politykami klimatycznymi}

Opisując polski dorobek w dziedzinie (nieekonomicznych) badań społecznych nad politykami klimatycznymi, warto wspomnieć o dwóch znakomitych książkach Marcina Popkiewicza, a mianowicie Świat na rozdrożu [2013] i Rewolucja energetyczna: Ale po co? [2015]. W pierwszej z nich Popkiewicz omawia wybrane cywilizacyjne zagrożenia, jak wyczerpywanie się ropy naftowej i innych surowców, utrata bioróżnorodności czy zmiany klimatu. Analizuje także cechy współczesnego, opartego na wzroście PKB, systemu ekonomicznego, które są przyczynami tych zagrożeń. Przedstawia następnie możliwe rozwiązania, jak 
np. wprowadzenie globalnego podatku węglowego czy systemu ekonomicznego, którego stabilność nie jest uzależniona od ciagłego wzrostu PKB, np. zaproponowanego przez Tima Jacksona [2009]. W drugiej książce Popkiewicz przedstawia rekomendacje dla Polski, prezentując pomysł na stworzenie, samowystarczalnego i opartego na lokalnych, odnawialnych źródłach systemu energetycznego. Zdaniem Popkiewicza sposobem na rozwiązanie problemu niestabilności części odnawialnych źródeł energii jest zachowanie odpowiednich proporcji pomiędzy nimi (wykorzystywanie energii wiatrowej nocą i zimą, a energii słonecznej latem oraz za dnia), a także pozyskiwanie stabilnej energii z biomasy, inwestowanie w magazynowanie energii oraz w efektywność energetyczną. Pomimo że w książkach przeważa perspektywa nauk przyrodniczych, technicznych oraz ekonomii, są one moim zdaniem bardzo dobrym wprowadzeniem także do ogólnych społecznych przyczyn i konsekwencji wybranych zagrożeń cywilizacyjnych, jak również do potencjalnych działań zapobiegawczych, w tym przeprowadzenia głębokich zmian społecznych.

Polscy badacze społeczni zajmowali się problemami antropocenu [Bińczyk 2018], dyskursami medialnymi wokół energetyki [Wagner 2016], specyfiką polityki klimatycznej w Polsce [np. Kundzewicz, Matczak 2012] czy zjawiskiem negacjonizmu klimatycznego [Bińczyk 2013]. Analizie poddano percepcję zagrożeń naturalnych przez lokalnych interesariuszy [Lackowska, Nowicka, Balandin, Grochowski 2016]. Zagrożenia związane z inżynierią klimatu przestudiowała natomiast Ewa Bińczyk [2015]. Problemem zbyt małego wykorzystania nieekonomicznych nauk społecznych w głównym nurcie badań i polityki klimatycznej zajął się natomiast Andrzej Strzałkowski [2016].

Uwagę socjologów i antropologów przyciągnęła także problematyka działalności grup interesów w sferze polityki energetycznej. Wyróżnić można opracowanie ogólnej ramy teoretycznej i analizę wpływu sfery politycznej na sektor energetyczny [Ruszkowski 2015], badanie lobbingu polskich związków zawodowych [np. Bernaciak, Lis 2017], czy analizę negocjacji przy tworzenia unijnego systemu handlu uprawnieniami do emisji [Lis 2011]. Bardzo interesujące są także badania nad metodami zarządzania w przemyśle naftowym i paliwowym, w tym w Polsce [Heinrich, Lis, Pleines 2005]. Rozwiniętym obszarem są badania na temat problematyki wydobycia gazu łupkowego w Polsce [np. Lis, Stankiewicz 2017; Wagner 2015]. Istnieją także badania skupiające się na gminnych politykach przeciwdziałania i adaptacji do zmian klimatycznych [np. Lackowska, Swianiewicz 2017; Szmigiel-Rawska 2017], w tym porównawcze badania międzynarodowe [np. Klausen, Szmigiel-Rawska 2017], a także analizujące potencjał 
i bariery wykorzystania crowdfundingu we wspieraniu innowacji w sektorze zielonej energii [Stasik 2018].

Jeżeli chodzi o wykorzystanie (opisanych w niniejszej pracy) teorii praktyk społecznych, perspektywy wielopoziomowej i podejścia behawioralnego, to można wskazać, na przykład, na następujący polski wkład. Powstało szereg prac społecznych wykorzystujących teorię praktyk społecznych, np. w badaniach nad praktykami parkowania [Smagacz-Poziemska, Bukowski, Kurnicki 2018] czy pojęciem jakości w alternatywnych sieciach żywnościowych [Goszczyński, Wróblewski, Wójtewicz 2018]. Wspólne wykorzystanie perspektywy wielopoziomowej i teorii reprezentacji społecznej Moscovici zaproponowali Paul Upham, Aleksandra Lis, Hauke Riesch i Piotr Stankiewicz [2015], bazując na analizie projektów wydobycia gazu łupkowego w Polsce, Niemczech i Wielkiej Brytanii. Perspektywa wielopoziomowa została także wykorzystana do analizy roli społecznej odpowiedzialności biznesu w zrównoważonej tranzycji (sustainability transition) [Daszyńska-Żygadło, Ryszawska 2015].

Ogólnego wprowadzenia do podejścia behawioralnego (behawioralnych interwencji publicznych, BIP) dokonali Karol Olejniczak i Paweł Śliwowski [2014]. Wpływ oddziaływań behawioralnych na rozwój małych i średnich przedsiębiorstw został opisany w pracy zbiorowej pod redakcją Przemysława Kulawczuka i Andrzeja Poszewickiego [2016]. Dokonano także prezentacji możliwości wykorzystania podejście behawioralnego (w formie libertariańskiego paternalizmu) w samorządowej polityce mieszkaniowej [Brzezicka, Wiśniewski, Napiórkowska-Baryła 2016]. Próby wspólnego wykorzystania podejścia behawioralnego (w formie COM-B), teorii praktyk społecznych i innych perspektyw dokonał natomiast Andrzej Strzałkowski [2018].

Jak wynika z powyższego przeglądu, badania nad szeroko pojętymi politykami klimatycznymi, a także badania w ramach teorii praktyk społecznych, perspektywy wielopoziomowej i podejścia behawioralnego w Polsce swoje początki mają już dawno za sobą. Nawiązano także współpracę międzynarodową, a prace polskich naukowców należą do głównego nurtu badań międzynarodowych. Pozytywnym zwiastunem dalszego rozwoju badań w tych kierunkach może się też okazać powstanie Sekcji Socjologii Środowiska Polskiego Towarzystwa Socjologicznego czy przyznanie grantów na badania w obszarze socjologii i antropologii środowiska [https://socjologiasrodowiska.wordpress.com/2017/11/29/ nowe-projekty-ncn-z-socjologii-srodowiska/]. Pomimo tego wciąż istnieje pilna potrzeba zwiększenia polskich wysiłków badawczych w wyżej wymienionych dziedzinach. $Z$ jednej bowiem strony skala polskich badań społecznych, zwłaszcza mających praktyczne zastosowanie w politykach klimatycznych, wciąż w mojej 
opinii odstaje od tych prowadzonych w Europie Zachodniej i Północnej. Z drugiej strony Polska, jako kraj produkujący znaczną część energii z paliw kopalnych, ma do odegrania istotną rolę w europejskiej oraz światowej polityce klimatycznej i zrównoważonego rozwoju, a jednocześnie proces transformacji energetycznej wydaje się tutaj szczególnie trudny i skomplikowany.

\section{Cel i struktura artykułu}

Celem niniejszego artykułu jest zaprezentowanie podstawowych założeń teorii praktyk społecznych, perspektywy wielopoziomowej i podejścia behawioralnego, a także możliwych implikacji tych podejść dla badań użytecznych w polityce klimatycznej (polityka mitygacyjna i adaptacyjna). Jednocześnie chciałbym uzupełnić wywód teoretyczny wskazaniem na wybrane badania empiryczne opisane w literaturze. Szczególny nacisk zostanie położony na teorię praktyk społecznych, ponieważ z jednej strony uzupełnia ona braki podejścia behawioralnego - gdyż odchodzi od perspektywy indywidualistycznej [Shove 2010] - a z drugiej strony nie jest zwykłą perspektywą strukturalną, z której prawdopodobnie trudno byłoby wyciągnąc jakieś praktyczne implikacje do działania [Blue, Shove, Carmona, Kelly 2016: 37-38]. Razem z teorią praktyk chciałbym opisać także perspektywę wielopoziomową która oferuje dosyć jasną konceptualizację zrównoważonej zmiany społecznej, a jednocześnie raczej łatwo poddaje się integracji z teorią praktyk. Ponadto zdecydowałem się też na równoległe wprowadzenie podejścia behawioralnego, które jest wypróbowaną formą wykorzystania perspektyw psychologicznych w politykach publicznych, a jednocześnie przyjmuje bardziej realistyczne założenia dotyczące ludzkiego zachowania aniżeli ekonomia neoklasyczna. Na przykład, nie zakłada, że człowiek jest w pełni „,racjonalny”, ale bierze pod uwagę istotną rolę norm społecznych, tendencji do naśladownictwa czy wielu błędów poznawczych i heurystyk myślowych w jego działaniach.

Struktura niniejszego artykułu jest następująca: w kolejnej części opisałem podstawowe założenia teorii praktyk społecznych, perspektywy wielopoziomowej i podejścia behawioralnego, w części trzeciej zaproponowałem sposób na wspólne wykorzystanie tych trzech perspektyw, natomiast w części czwartej zaprezentowałem przykładowe kierunki badań rozwijające się w omawianych perspektywach, a także przykładowe metody badawcze. Artykuł kończy krótkie podsumowanie ze wskazaniem na potencjalne kierunki dalszych badań. 


\section{OPIS WYKORZYSTANYCH PERSPEKTYW TEORETYCZNYCH}

\section{Teoria praktyk spolecznych}

Teoria praktyk społecznych (social practice theory, theories of social practice) jest perspektywą teoretyczną zakorzenioną w pracach takich autorów, jak m.in. Anthony Giddens, Pierre Bordieu, Michael Focault, Martin Heidegger, Ludwig Wittgenstein czy Karol Marks [Blue, Shove, Carmona, Kelly 2016: 41]. W wersji opracowanej przez Elizabeth Shove, Mika Pantzar i Matta Warsona [2012] zakłada ona, że życie społeczne konstytuuje wielość wzajemnie powiązanych i oddziałujących na siebie praktyk społecznych. Praktykę można zrozumieć jako rutynowe zachowanie [Shove, Pantzar, Watson 2012: 6]. Ponadto można wyróżnić definicję praktyki jako jednostki analitycznej (practice-as-entity) oraz praktyki jako odegrania (practice-as-performance).

Praktyka jako jednostka analityczna składa się z trzech rodzajów wzajemnie powiązanych i oddziałujących na siebie elementów, takich jak materiały (np. samochód, stacja benzynowa), kompetencje (np. umiejętność prowadzenia samochodu, rozpoznawania znaków drogowych) i znaczeń (samochód jako symbol statusu i wolności). Natomiast praktyka jako odegranie to po prostu widziana przez nas czynność wykonywana przez ludzi, np. ludzie jadący samochodem. Praktyki jako odegrania reprodukują (reproduct) praktyki jako jednostki analityczne, natomiast praktyki jako takie jednostki w dużej mierze uwarunkowują praktykę jako odegranie. Sama teoria przewiduje też to, że praktyki mogą wzajemnie na siebie oddziaływać, konkurować ze sobą czy zdobywać i tracić wykonawców (practitioners).

Teoria praktyk opiera się ponadto między innymi na dwóch ważnych założeniach. Po pierwsze, jest ona perspektywą, ,pośredniego" typu, a więc nie zakłada ani kluczowej roli agencji, ani kluczowej roli struktur społecznych w kształtowaniu dynamiki życia społecznego. Czerpiąc z teorii strukturacji Giddensa [Shove, Pantzar, Warson 2012: 3-4], zakłada, że rzeczywistość społeczna składa się z wielości dynamicznych praktyk społecznych, które w pewnym sensie utożsamiają zarówno możliwość kształtowania rzeczywistości przez poszczególne jednostki, jak i jednoczesne oddziaływanie zewnętrznych wobec nich struktur społecznych. Po drugie, teoria praktyk posiada tzw. ,płaską ontologię" [Schatzki 2015: 16], co oznacza, że wyjaśnia rzeczywistość za pomocą wielu praktyk społecznych, których konstytutywne cechy są takie same. Nie przewiduje więc żadnych, różniących się swoją istotą „poziomów” społecznych, czy innych zewnętrznych wobec praktyk lub innych od praktyk zjawisk. 
Ważną kwestią z punktu widzenia polityki klimatycznej jest to, że zastosowanie teorii praktyk nie implikuje nowych, szczególnych metod interwencji publicznych [Blue, Shove, Carmona, Kelly 2016: 45-47]. Proponuje ona natomiast nowe sformułowanie różnych problemów społecznych, które to sformułowanie wywiera z kolei wpływ na ocenę, jakiego rodzaju metody interwencji z dotychczas stosowanych mogą przenieść lepszy skutek, zmianę sposobu, w jaki te metody są wykorzystywane oraz przedmiotu samych interwencji, którym stają się praktyki społeczne. Opierając się na teorii praktyk, można wyróżnić trzy formy interwencji w społeczne praktyki, mianowicie przerobienie praktyk (re-crafting practices), substytucję praktyk (substituting practices) i zmianę sposobu, w jaki różne praktyki są ze sobą powiązane, czy się przeplatają (changing how practices interlock).

Przerobienie praktyk polega na zmianie lub modyfikacji ich elementów na bardziej zrównoważone (w kontekście polityki klimatycznej). Metody interwencji nie różnią się tutaj od dotychczasowych metod używanych w politykach klimatycznych, kładzie się jednak nacisk na systematyczną analizę i branie pod uwage wszystkich rodzajów elementów praktyk oraz ich specyficznych relacji [Spurling, McMeekin, Shove, Southerton, Welch 2013: 9-10]. Przykładem przerabiania będzie na przykład wprowadzanie elektrycznych samochodów, nauczanie ekologicznej jazdy czy promowanie car-sharingu. Substytucja natomiast polega na zastępowaniu jednej praktyki inną, bardziej zrównoważoną. Nie wiąże się więc ona z uczynieniem danej praktyki bardziej zrównoważona, ale z wprowadzeniem zamiast niej kompletnie innej praktyki, która może spełniać te same potrzeby czy pragnienia [Spurling, McMeekin, Shove, Southerton, Welch 2013: 11-12]. Tutaj przykładem może być zastępowanie jazdy samochodem jazdą rowerem.

Zmiana sposobu, w jaki różne praktyki się przeplatają (są powiązane), jest chyba najbardziej wartościową dla polityki klimatycznej formą interwencji (z tutaj wymienionych), ponieważ tego rodzaju możliwość jest często niezauważana [Spurling, McMeekin 2015: 78-79]. Najpierw jednak chciałbym zobrazować, jakiego rodzaju formy przeplatania mogą istnieć pomiędzy praktykami. Pierwszą jego formą będzie sytuacja, kiedy dwie praktyki dzielą wspólny element lub elementy, przykładem może być jazda na rowerze po jezdni dla samochodów. Drugim rodzajem będzie przeplatanie się czasowe, a więc wykonywanie pewnych praktyk w jednym momencie, czy konieczność ich synchronizacji, jak np. chłodzenie mieszkań klimatyzacją i jednoczesna produkcja energii. Trzecim będzie przeplatanie się przestrzenne, a więc np. wykonywanie określonych praktyk $w$ tym samym miejscu, czy ich przestrzenna koordynacja, czego przykładem może być palenie w starym piecu w domu i konieczność ograniczania aktywności fizycznej przez mieszkańców z powodu smogu. 
Ponadto warto zasygnalizować, że różnego rodzaju powiązania między praktykami mogą prowadzić do powstania ich wiązek (bundles), a więc praktyk luźno powiązanych, opartych np. na wspólnej lokalizacji czy to koegzystencji, czy kompleksów (complexes). Powiązania w kompleksach są tak ścisłe, że jedna praktyka zależy od innej; tworzą ponadto nową całość, która nie jest redukowalna do jej elementów [Shove, Pantzar, Watson 2012: 87]. Ponadto można także wprowadzić pojęcie praktyki komponentowej, które oznacza praktykę składającą się $\mathrm{w}$ istocie z kilku innych praktyk, czego przykładem może być praktyka jedzenia składająca się z praktyk dostaw żywności, gotowania, organizowania posiłków i ,estetycznych orzeczeń o smaku”, czyli praktyki gastronomii [Warde 2014].

Same interwencje zmieniające to, jak praktyki są wzajemnie powiązane, mogą się więc opierać na przykład na tworzeniu wielofunkcyjnych budynków, pozwalających na wykonywanie wielu praktyk, jak m.in. praca, rozrywka czy spotkania w tym samym miejscu i czasie, co jednocześnie zmniejsza konieczność korzystania z transportu (osłabienie kompleksów praktyk). W tego rodzaju miejscach mogą być zapewnione różnego rodzaju przedmioty czy usługi niezbędne do odgrywania tych praktyk, jak np. ławki, stoły, pomieszczenia, czy Internet, a więc elementy mogące być wykorzystane przez różne praktyki [Spurling, McMeekin, Shove, Southerton, Welch 2013: 13]. Innym przykładem jest wprowadzenie zakazu palenia $\mathrm{w}$ restauracjach, co z jednej strony rozrywa wiązkę praktyk, ale z drugiej strony może prowadzić do powstania nowej wiązki, wpływającej na sam charakter praktyki palenia, czyli palenia na zewnątrz [Blue, Shove, Carmona, Kelly 2016].

Wykorzystanie niniejszej teorii $\mathrm{w}$ badaniach nad politykami społecznymi może być owocne, moim zdaniem, z kilku względów. Po pierwsze, odchodzi ona od indywidualistycznej perspektywy dominującej w głównym nurcie badań nad polityką klimatyczną, co może być szansą na bardziej skuteczne i dogłębne zmiany, a tym samym na bardziej celowe wykorzystanie wysiłków badawczych [Shove 2010: 1280-1283]. Po drugie, oferuje szeroką, a jednocześnie szczegółową perspektywę na życie społeczne. Może to ułatwić konstruowanie konkretnych interwencji publicznych dostosowanych do danego kontekstu. Po trzecie wreszcie, jest ona perspektywą dynamicznie się rozwijającą i coraz bardziej rozpoznawalną, z tego też względu może stać się istotnym czynnikiem integrującym badania socjologiczne z głównym nurtem badań nad polityką klimatyczną. 


\section{Perspektywa wielopoziomowa i podejście behawioralne}

Perspektywa wielopoziomowa (multi-level perspective) jest perspektywą teoretyczną pod pewnymi względami podobną do teorii praktyk społecznych, ale o ile ta pierwsza koncentruje się raczej na złożoności i wzajemnym oddziaływaniu na siebie różnych praktyk, o tyle perspektywa wielopoziomowa rzuca światło przede wszystkim na proces przejść (transitions) od jednej konfiguracji systemów społeczno-technicznych do innej. Wykorzystuje ona koncepcje z ekonomii ewolucyjnej, studiów nad nauką i techniką (science and technology studies), teorii strukturacji i teorii neoinstytucjonalnej [Geels 2011: 26].

Generalnie rzecz biorąc, perspektywa wielopoziomowa stara się opisać proces przejść systemów społeczno-technicznych dokonujący się dzięki interakcji trzech „poziomów” analitycznych, a mianowicie niszy (niche), czyli praktyk i technologii, które nie są rozpowszechnione i mają słabą pozycję w danej konfiguracji, reżimu (regime), czyli dominującego układu praktyk i technologii, jak również krajobrazu (landscape), czyli procesów będących poza wpływem poszczególnych aktorów społecznych. Proces tranzycji może przebiegać na przykład w ten sposób, że dynamicznie rozwijająca się innowacja i silne oddziaływania krajobrazu destabilizują reżim, który jest następnie zastępowany przez innowację [Geels 2002: 1261-1263]. W tym miejscu warto również zauważyć, że wraz z perspektywą wielopoziomową rozwija się również nurt zarządzania przejściami (transition management), który stara się wypracować strategie celowego wywoływania zrównoważonych przejść. Spotkał się on jednak z ostrą krytyką przedstawicieli teorii praktyk społecznych, m.in. z powodu braku adekwatnego uwzględnienia złożoności społecznego życia codziennego, braku wyraźnego zdefiniowania granic zarządzania, utrzymywania stanowiska o braku „managerów” w procesie zarządzania przejściem oraz, wreszcie, braku adekwatnego uwzględnienia problematyki polityki i władzy [Shove, Walker 2007].

Podejście behawioralne do interwencji publicznych to generalnie forma zastosowania psychologii poznawczej i społecznej do konstruowania interwencji publicznych. Wywodzi się ona między innymi z badań psychologów Amosa Tversky'ego i Daniela Kahnemana nad heurystykami i błędami poznawczymi popełnianymi systematycznie przez ludzki umysł [Olejniczak, Śliwowski 2014: 15-19]. Podejście rozpowszechnione zostało przez Cassa Susteina i Richarda Thalera w książce Nudge [Olejniczak, Śliwowski 2014: 20], a obecnie jest promowane m.in. przez takie instytucje, jak Bank Światowy [World Bank 2015], Komisja Europejska [Sousa, Ciriolo, Almeida, Troussard 2016] czy Organizacja Współpracy Gospodarczej i Rozwoju [OECD 2017]. Podstawowymi założeniami 
leżącymi u podstaw tego podejścia jest możliwość wykorzystania wiedzy psychologicznej o ludzkim myśleniu i zachowaniu, w tym o uleganiu wpływowi społecznemu, w politykach publicznych. Powinno to prowadzić do zwiększenia ich efektywności, czasem dzięki dosyć drobnym i prostym interwencjom.

Wykorzystanie perspektywy wielopoziomowej w badaniach nad polityką klimatyczną posiada tę zaletę, że umożliwia dokonanie stosunkowo prostej, a jednocześnie - jak sądzę - trafnej analizy zmiany społecznej. W swojej analizie bierze pod uwagę wiele czynników występujących w systemach społeczno-technicznych, które, działając wspólnie, wpływają na dynamikę zrównoważonych przejść. Posiada też potencjał do wprowadzenia do niej koncepcji i sposobów analizy wykorzystywanych w ekonomii politycznej, a więc również analizy relacji władzy [Geels 2014].

Skorzystanie z podejścia behawioralnego umożliwia natomiast bardziej psychologiczne spojrzenie. $Z$ jednej strony jest ono indywidualistyczne, pomija więc istotne kwestie strukturalne ( $\mathrm{z}$ tego względu wymaga wykorzystania razem z podejściami bardziej socjologicznymi, jak np. teoria praktyk i perspektywa wielopoziomowa). $Z$ drugiej jednak strony oferuje wiele bardzo prostych i praktycznych sposobów wpływu na ludzkie zachowania. O ile korzystanie tylko z oferowanych przez podejście behawioralne strategii i technik interwencji może nie być skuteczne w świetle polityk klimatycznych, o tyle ich wykorzystanie w połączeniu z obserwacjami i badaniami opartymi na teorii praktyk oraz perspektywie wielopoziomowej może stanowić istotną wartość dodaną, przede wszystkim do pierwszej, ale również do tych drugich. Na przykład podejście behawioralne może w znacznym stopniu wzmacniać efekty interwencji sformułowanych w ramach dwóch pozostałych podejść, jak również doprecyzowywać je o behawioralne szczegóły (np. sposób formułowania komunikatów do adresatów).

\section{WSPÓLNE WYKORZYSTANIE PERSPEKTYW TEORETYCZNYCH W BADANIACH NAD POLITYKĄ KLIMATYCZNĄ}

Po odrębnym zaprezentowaniu powyższych trzech perspektyw teoretycznych pozostaje istotny problem związany z ich wspólnym wykorzystaniem [por. Shove 2011: 263-264]. Jako punkt wyjścia chciałbym zaproponować podejście wykorzystujące hierarchię tych perspektyw [Strzałkowski 2018]. Hierarchia ta polegałaby na tym, że co do zasady perspektywa wyższa w hierarchii byłaby bardziej eksponowana i co do zasady na jej korzyść rozstrzygane byłyby potencjalne konflikty teoretyczne, które wyrażałyby się w sprzecznych implikacjach praktycznych dla polityki klimatycznej. W tym przypadku perspektywą najwyższą w hierarchii byłaby 
teoria praktyk społecznych, następnie perspektywa wielopoziomowa i wreszcie podejście behawioralne. Kolejność ta, jak sądzę, ma pewne uzasadnienie. O ile bowiem perspektywa wielopoziomowa szczegółowo i stosunkowo prosto opisuje sam proces zmiany społecznej, o tyle teoria praktyk oferuje bardziej szczegółowy wgląd w złożoność codziennego życia społecznego, w tym w elementy praktyk i powiązania między nimi. Z tego względu pierwszeństwo chciałbym przyznać teorii praktyk, która pomoże szczegółowo opisać dynamikę codziennego życia społecznego, a miejsce poniżej jej perspektywie wielopoziomowej, która oferuje szczegółowy opis samej zmiany społecznej. Podejściu behawioralnemu, z racji na to, że przyjmuje perspektywę indywidualistyczną i gorzej radzi sobie z bardziej „strukturalnym” spojrzeniem, przyznaję trzecią pozycję. Wykorzystując tego rodzaju hierarchiczne podejście, warto oczywiście pamiętać o tym, jakiego rodzaju perspektywy teoretyczne są w nim najbardziej eksponowane, a tym samym, do jakiego rodzaju problematyki badawczej to podejście jest najprzydatniejsze [myśl zaczerpnięta bezpośrednio z uwag anonimowych recenzentów artykułu Strzałkowski 2018].

Opisując i wyjaśniając wybrane sfery polityki klimatycznej przez pryzmat perspektywy podstawowej, a więc teorii praktyk społecznych, chciałbym od nowa sformułować zadanie tej polityki. Od teraz byłoby nim wpływanie na praktyki społeczne w taki sposób, aby zmniejszać emisję gazów cieplarnianych z nimi związanych lub uodpornić praktyki społeczne na zmiany klimatu już nieuniknione. Opierając się na tak sformułowanym problemie, interwencje mogą być więc sformułowane $\mathrm{w}$ formie przerabiania społecznych praktyk, ich substytucji lub zmiany tego, jak praktyki społeczne się przeplatają. Pozwoli to otworzyć swego rodzaju „czarną skrzynkę” złożoności codziennych ludzkich zachowań; pojęcie ,przeciętnego konsumenta” zostanie zastapione naciskiem na uchwycenie różnorodności, np. praktyki oświetlenia domu i dostosowania interwencji do tej różnorodności. Jednocześnie tworzący politykę klimatyczną powinni postrzegać siebie jako tylko jeden $\mathrm{z}$ wielu podmiotów wpływających na dynamikę praktyk społecznych [Schatzki 2015], jak również mieć świadomość ogromnej złożoności życia społecznego, a co za tym idzie, nieprzewidywalności skutków interwencji z samego założenia.

Przechodząc do perspektywy wielopoziomowej, warto odnieść się do potencjalnego konfliktu pomiędzy jej założeniami na temat trzech poziomów analitycznych a „płaską ontologią” teorii praktyk. W tym miejscu chciałbym skorzystać z sugestii Franka Geelsa [2011: 37] i potraktować te trzy poziomy nie jako ontologicznie różne zjawiska, a jedynie jako zbiory praktyk społecznych 
różniących się trwałością i stopniem rozpowszechnienia. Zabieg ten eliminuje potencjalnie najpoważniejszy konflikt teoretyczny pomiędzy oboma podejściami i nie wydaje się niezgodny z samą teorią praktyk, która może zakładać ich zróżnicowanie, np. jeżeli chodzi o zakres ich wpływu na inne [Watson 2016], czy nierównomierny rozkład elementów [Shove 2017].

Tego rodzaju ujęcie pozwala traktować perspektywę wielopoziomową jako swego rodzaju analityczną „,nakładkę” na teorię praktyk. Z jednej strony, jeżeli jest to przydatne, można wykorzystać perspektywę wielopoziomową do analizy relacji pomiędzy nisza, reżimem i krajobrazem, a z drugiej, zawsze można spojrzeć na te relacje jako na oddziaływania pomiędzy różnymi zbiorami społecznych praktyk. Korzystając z myśli Hansa Kelsena [2014], należy zauważyć, że trzy poziomy będą tutaj pojęciami pomocniczymi, które nie są niezbędne do opisania rzeczywistości społecznej tylko za pomocą teorii praktyk. Na koniec warto zauważyć, że jednoczesne wykorzystanie teorii praktyk i perspektywy wielopoziomowej (chociaż niekoniecznie w ten sposób) było już proponowane w literaturze [Berg, Buhl, Hasselkuß, Heller, Monetti, Stadler, Mönnikes, Suski, Thema 2016: 105-112], a z obu tych nurtów czerpał na przykład Matt Watson w swoim artykule o transporcie rowerowym [2014]. Ponadto wspólne wykorzystanie obu perspektyw będzie przynajmniej częściowym zrekompensowaniem niedostatków, jakie zarzuca się związanemu z perspektywą wielopoziomową zarządzaniu przejściami (transitions), np. w zakresie zbyt małego uwzględnienia złożoności społecznego życia codziennego.

Ostatnim krokiem będzie włączenie we wspólną perspektywę podejścia behawioralnego. W tym przypadku teoretyczna integracja nie jest już raczej możliwa ze względu na zbyt daleko idące różnice paradygmatyczne pomiędzy dwoma pierwszymi a tą perspektywą [por. Shove 2010]. W tym miejscu chciałbym jednak wykorzystać to, że zastosowanie teorii praktyk do sformułowania problemów polityki klimatycznej nie implikuje jakichś specyficznych metod interwencji, co moim zdaniem odnosi się zresztą również do perspektywy wielopoziomowej. Podejście behawioralne może więc rzucić światło na problemy istotne dla opracowywania szczegółów interwencji, podczas gdy problemy istotne dla ogólnych strategii i „miejsc” interwencji opisywałaby i wyjaśniała teoria praktyk z „nakładką” podejścia wielopoziomowego [Strzałkowski 2018]. W razie sprzecznych implikacji praktycznych podejście behawioralne co do zasady ustępowałoby miejsca perspektywom wyżej w hierarchii, co jest zobrazowane jako nakładanie się kół na schemacie 1. Również w tym wypadku pewne sugestie dotyczące wspólnego wykorzystania zarówno teorii praktyk, jak i podejścia 
behawioralnego można odnaleźć w literaturze [np. Darnton, Verplanken, White, Whitmarsh 2011].

SCHEMAT 1. Podejście hierarchiczne w zastosowaniu różnych perspektyw teoretycznych

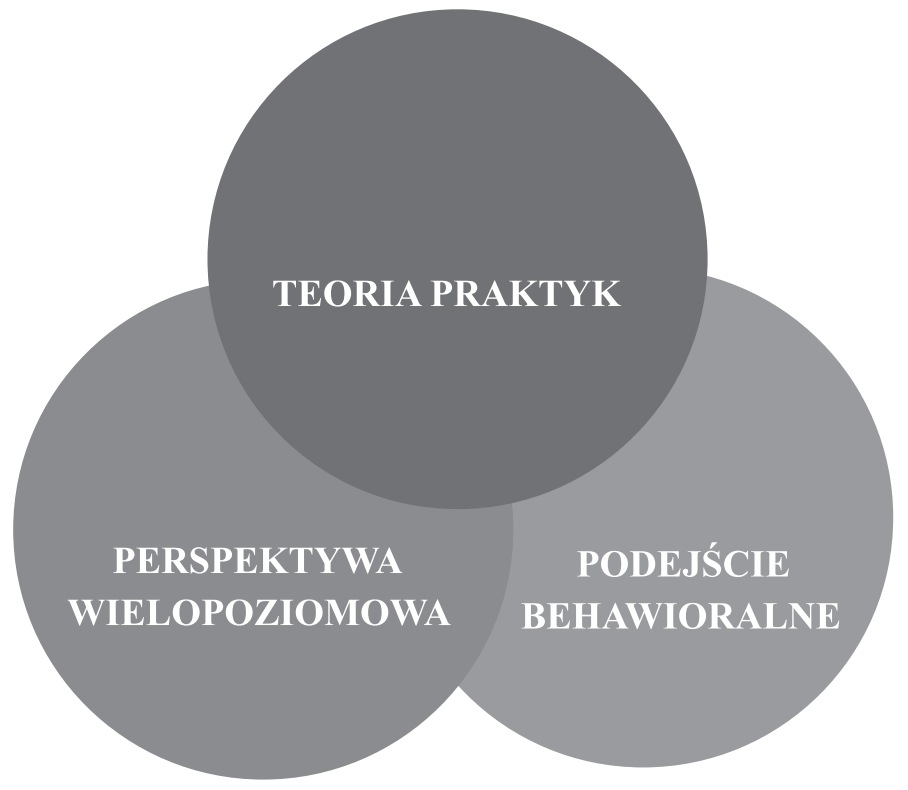

Źródło: Strzałkowski 2018.

Wszystkie z wybranych perspektyw i nurtów badawczych posiadają oczywiście zarówno swoje mocniejsze, jak i słabsze strony. Z jednej strony teoria praktyk społecznych, skupiając się na codziennych praktykach związanych z konsumpcją, mniej uwagi poświęca „stronie podażowej”. Perspektywa wielopoziomowa z kolei zbyt mocno koncentruje się na rozwoju technologii i społecznym kontekście innowacji, mniej uwagi poświęcając praktykom użytkowników [Geels, McMeekin, Mylan, Southerton 2015: 10]. Obie perspektywy krytykowano również ze względu na to, że poświęcają zbyt mało uwagi problematyce polityki i władzy, aczkolwiek wprowadzenie ekonomii politycznej do perspektywy wielopoziomowej [Geels 2014], a w mniejszej mierze konceptualizacja władzy w teorii praktyk [Watson 2016], pozwala te braki redukować. Oba nurtu rozwijają się więc zarówno teoretycznie, jak i empirycznie. Podstawowe „braki” podejścia behawioralnego mogą być moim zdaniem uzupełnione właśnie dzięki wykorzystaniu podejścia behawioralnego wraz z bardziej „socjologicznymi” perspektywami. 


\section{PRZYKLADOWE KIERUNKI WYKORZYSTANIA WYBRANYCH PERSPEKTYW W BADANIACH NAD POLITYKĄ PRZECIWDZIALANIA ZMIANOM KLIMATU}

Jeśli chodzi o potencjalne kierunki wykorzystania omawianych perspektyw w polityce klimatycznej, np. związanej z redukcją emisji gazów cieplarnianych, to teoria praktyk może dostarczyć oglądu tego, jak energochłonne praktyki są uwikłane w ciąg życia codziennego mieszkańców danego obszaru, jak powiązania energochłonnych praktyk z innymi codziennymi praktykami mogą utrudniać zmianę tych pierwszych (np. za pomocą prostych programów dofinansowania) i jakie formy interwencji w praktyki można tutaj zastosować. Podobne pytania można postawić na temat możliwości i trudności w rozwoju ruchu prosumenckiego, w tym konsekwencji produkcji energii w źródłach odnawialnych dla całego szeregu innych codziennych praktyk. Warto zauważyć, że istniejąjuż rozwinięte badania nad tą tematyką, można wspomnieć choćby o analizie relacji inteligentnych sieci i praktyk społecznych [Smale, van Vliet, Spaargaren 2017]. Również badania ilościowe w nurcie teorii praktyk nad problemami istotnymi dla polityk klimatycznych rozwijają się coraz szybciej, w tym miejscu wspomnieć można o badaniach z zakresu oświetlenia w gospodarstwach domowych [Monreal, McMeekin, Southerton 2016].

Doskonałym „przedłużeniem” form interwencji wypracowanych z wykorzystaniem wiedzy uzyskanej z badań zainspirowanych teorią praktyk może być wiedza uzyskana w wyniku zastosowania podejścia behawioralnego, które może dostarczyć wyjaśnień przydatnych do tego, w jaki sposób formułować komunikaty skierowane do mieszkańców, jak ułatwiać procedury administracyjne związane z uzyskiwaniem dofinansowań, czy jak motywować bardziej dynamiczne rozpowszechnianie się pewnych pomysłów. Przykładów wykorzystania wiedzy uzyskanej za pomoca podejścia behawioralnego w politykach publicznych jest bardzo wiele, wystarczy wspomnieć np. o wykorzystaniu ludzkiej tendencji do dostosowywania się do norm społecznych w celu promowania oszczędności energii w gospodarstwach domowych [World Bank: 167-168] i w miejscu pracy [OECD 2017: 112], czy o przykładzie wykorzystania inteligentnych liczników [OECD 2017: 118]. Dziesiątki innych przykładów zastosowania wiedzy behawioralnej w bardzo różnych dziedzinach, jak ściąganie podatków, nadzór nad rynkiem finansowym, zdrowie publiczne czy rynek pracy, znaleźć można w raportach wielu organizacji pozarządowych [np. OECD 2017; Sousa, Ciriolo, Almeida, Troussard 2016; World Bank 2015]. Badania te można również wykorzystać w politykach klimatycznych. 
Perspektywa wielopoziomowa z kolei może być przydatna do umiejscowienia wybranych podmiotów publicznych i prywatnych w szerszej perspektywie dominującego reżimu energetycznego. Może także służyć wskazaniu na możliwości rozwoju niszy, jaką są odnawialne źródła energii, przy jednoczesnym wykorzystaniu sprzyjających warunków krajobrazu. Jeśli chodzi o dotychczasowe badania, to warto wspomnieć tutaj choćby o teoretycznym opisaniu roli miast w społeczno-technicznych przejściach [Ernst, de Graaf-Van Dinther, Peek, Loorbach 2016], ale też o badaniach empirycznych dotyczących czynników sprzyjających transformacji energetycznej w Niemczech [Kungl, Geels 2017].

Wśród metod badawczych wykorzystywanych w badaniach empirycznych wskazać można przede wszystkim na wywiady jakościowe, studia przypadków, badania ankietowe i eksperymenty z grupą kontrolną. Wywiady częściowo ustrukturyzowane, z pytaniami opartymi na teorii są szeroko wykorzystywane jako główna metoda (w obrębie konkretnego badania) w teorii praktyk społecznych [m.in. Brons, Oosterveer 2017; też wywiady grupowe, m.in. Cruz, Katz-Gerro 2016], jak też w przypadku perspektywy wielopoziomowej, chociaż w tym wypadku raczej rzadziej [de Boer, Caprotti 2017].

Oprócz metod czysto jakościowych stosowane są również studia przypadku $\mathrm{z}$ wykorzystaniem danych o różnym charakterze, w tym ilościowym. Warto zauważyć, że tego rodzaju metoda jest z kolei bardzo popularna w perspektywie wielopoziomowej [m.in. Kungl, Geels 2017], w której często porównuje się studia przypadków różnych przejść (transitions) pomiędzy reżimami społeczno-technicznymi.

Wykorzystuje się także badania ankietowe, zarówno w formie danych uzyskanych od prywatnych podmiotów [Monreal, McMeekin, Southerton 2016: 40], jak i badania zlecone przez samych badaczy firmie badań rynkowych [Pullinger, Browne, Anderson, Medd 2013: 12]. Analizy ilościowe często spotykane są nie tylko w przypadku perspektywy wielopoziomowej, ale również w teorii praktyk społecznych [Monreal, McMeekin, Southerton 2016; Pullinger, Browne, Anderson, Medd 2013], a za ich stosowaniem przemawia argument, że uchwycenie wielu zjawisk może być bardzo trudne w przypadku badań na mniejszych próbach lub badań etnograficznych, a jednocześnie badania ilościowe mogą mieć większy walor praktyczny z perspektywy przedstawicieli administracji i przemysłu [Browne, Medd, Anderson, Pullinger 2015: 191-192].

Jeżeli chodzi o kwestię dostępności danych już istniejących w Polsce, to przedstawia się ona w zróżnicowany sposób. Z jednej strony GUS oferuje wiele danych bardzo przydatnych z perspektywy teorii praktyk, perspektywy wielopoziomowej i podejścia behawioralnego. Są to między innymi dane zebrane w pu- 
blikacjach Budżet czasu ludności 2013 (szeroki wachlarz informacji o długości trwania poszczególnych społecznych praktyk czy ich rozkładzie na przestrzeni dnia), a także publikacjach związanych z Narodowym Spisem Powszechnym z 2011 roku i Budżetami gospodarstw domowych, które przedstawiają wiele danych na temat wyposażenia mieszkań czy ich rodzajów. Część przydatnych danych można również pozyskać od innych urzędów, a także spółek komunalnych lub podmiotów komercyjnych.

Statystyki GUS mają swoje ograniczenia. Na przykład publikacja Zużycie energii w gospodarstwach domowych w 2015 r., pomimo że porusza tematykę żarówek, nie opisuje szczegółowo, jakiego typu żarówki są używane w konkretnych pomieszczeniach, co było kluczowym elementem jednego z badań na temat wykorzystania oświetlenia [Monreal, McMeekin, Southerton 2016]. Podczas telefonicznej konsultacji z przedstawicielką GUS dowiedziałem się, że tego rodzaju dane nie będą również raczej dostępne w wersji ,surowej”, podobnie jak dane o praktykach związanych z wykorzystaniem wody, między innymi tego, czy mieszkańcy preferują kąpiel, czy prysznic, lub jak często robią pranie, co zaliczało się do kluczowych elementów kolejnego badania z teorii praktyk [Pullinger, Browne, Anderson, Medd 2013]. Zdaniem przedstawicielki GUS raczej nie posiadają podobnie szczegółowych danych podmioty komercyjne, bądź posiadają je w bardzo ograniczonym zakresie.

\section{PODSUMOWANIE I KIERUNKI DALSZYCH BADAŃ}

Badania społeczne nad zmianami klimatu i polityką klimatyczną rozwijają się intensywnie zarówno w sferze teoretycznej, jak i empirycznej, co pozwala na wypełnienie znacznej luki poznawczej, która powstała w związku z dotychczasową dominacją w tej dziedzinie nauk przyrodniczych, technicznych i ekonomii. Niezbędne są jednakże dalsze wysiłki badawcze, zarówno na gruncie polskim, na którym takie perspektywy jak teoria praktyk społecznych czy perspektywa wielopoziomowa mogą rzucić nowe światło na wiele problemów, jak też na gruncie międzynarodowym.

Jeżeli chodzi o potencjalne kierunki międzynarodowych wysiłków badawczych, to warto, po pierwsze, zauważyć, że programy i polityki oparte na opisach oraz wyjaśnienia dokonane za pomocą teorii praktyk społecznych znajdują się w bardzo wczesnej fazie rozwoju [Strengers, Moloney, Maller, Horne 2015]. Opracowanie potencjalnych rozwiązań służących osadzeniu implikacji teorii praktyk w kontekście zarządzania publicznego byłoby bardzo istotnym wkła- 
dem w rozwój tego kierunku. Istotne może być również samo zaproponowanie kierunków interwencji pilotażowych, jak zrobiono np. w kontekście sklepów bez opakowań we Włoszech [Rapp, Marino, Simeoni, Cena 2017]. Jednocześnie warto zauważyć, że istnieją już prace empiryczne analizujące istniejące interwencje publiczne przez pryzmat teorii praktyk społecznych, które mogą być podstawą do kolejnych badań tego typu oraz do interwencji pilotażowych wykorzystujących wiedzę zdobytą za pomocą tej teorii [np. Hausknost, Haas, Hielscher, Schäfer, Leitner, Kunze, Mandi 2018].

Po drugie, niezwykle istotne może być zastosowanie zarówno jakościowej, jak i ilościowej metodologii, np. zakładającej przeprowadzenie ankietowych badań reprezentatywnych. Tego rodzaju metody ilościowe zastosowano $\mathrm{w}$ badaniach praktyk związanych $\mathrm{z}$ oświetleniem domowym - dane zostały zebrane techniką wywiadów internetowych, przeprowadzonych przez członków panelu supermarketu na próbie 1458 dorosłych osób, a następnie przeanalizowane przez zespół badawczy [Monreal, McMeekin, Southerton 2016: 40]. Podobnie wyglądały badania nad praktykami związanymi z wykorzystaniem wody, przeprowadzone na reprezentatywnej próbie 1802 gospodarstw domowych, w których dane zostały zebrane przez firmę zajmującą się badaniami rynkowymi, a przeanalizowane przez zespół badawczy [Pullinger, Browne, Anderson, Medd 2013: 12]. Warto jednak zauważyć, że tego rodzaju badań w obszarze teorii praktyk jest nadal niewiele, gdyż przeważają tam badania historyczne i jakościowe [Browne, Medd, Anderson, Pullinger 2015: 181, 190]. Trzeba też dodać, że w znacznej mierze nie są one dostępne w standardowych statystykach, np. prowadzonych przez polski GUS.

Istotnym wkładem tego rodzaju badań jest to, że umożliwiają one zobrazowanie stopnia rozpowszechnienia i rozkładu danego rodzaju praktyk, co jest trudne w przypadku badań na małych próbach i badań etnograficznych. Ponadto za bardzo ważne należy uznać, że tego rodzaju ilościowe lub mieszane metodologie badawcze mają duży potencjał umożliwiający ich wykorzystanie przez przemysł, a także w procesie formułowania problemów w politykach publicznych, które to wykorzystanie nie będzie ograniczać się do utartych schematów ekonomicznych i technologicznych [Browne, Medd, Anderson, Pullinger 2015: 191-192].

Po trzecie, wartościowe może być również jednoczesne wykorzystanie teorii praktyk i perspektywy wielopoziomowej, już wcześniej proponowane w literaturze [Berg, Buhl, Hasselkuß, Heller, Monetti, Stadler, Mönnikes, Suski, Thema 2016: 105-112]. Po czwarte, prawdopodobnie nowatorskim rozwiązaniem jest jednoczesne wykorzystanie w praktyce dwóch poprzednich podejść wraz z podejściem behawioralnym do interwencji publicznych, chociaż istnieją tego rodzaju 
propozycje i prowadzone są próby [np. Darnton, Verplanken, White, Whitmarsh 2011]. Jest to bardzo istotny temat, zwłaszcza że zarówno socjologiczne, jak i psychologiczne badania posiadają znaczny potencjał praktyczny, a dotychczas często podkreślało się przede wszystkim paradygmatyczne różnice pomiędzy nimi.

Po piąte, istotnym problemem jest systematyczne wykorzystanie podejścia behawioralnego w polityce publicznej [OECD 2017: 13-14; Sousa, Ciriolo, Almeida, Troussard 2016: 8]. Po szóste wreszcie, zbadanie polskiego kontekstu w niniejszej tematyce powinno również budzić zainteresowanie międzynarodowe, szczególnie że Polska znajduje się w pewnej „,pośredniej” fazie rozwoju polityki klimatycznej i jest nietypowym przypadkiem ze względu na bardzo wysoki poziom wykorzystania węgla w produkcji energii [Kundzewicz, Matczak 2012]. Po siódme, warto kontynuować badania nad przyczynami słabej popularności nieekonomicznych nauk społecznych w głównym nurcie badań i polityki klimatycznej, jak też kontynuować starania zmierzające do ich integracji w tym nurcie [Strzałkowski 2016: 465-467].

Wszystkie wymienione powyżej kierunki rozwoju badań międzynarodowych można również odnieść do badań polskich. W ich przypadku warto jednak dodatkowo zauważyć, że wykorzystanie teorii praktyk, perspektywy wielopoziomowej i podejścia behawioralnego może rzucić nowe światło na wiele problemów polskiej polityki klimatycznej, w której jak dotychczas dominuje raczej podejście ekonomiczne i techniczne aniżeli szersze podejście socjologiczne czy podejście behawioralne. Może to umożliwić wniesienie istotnego wkładu do badań polskich i pomóc w odpowiedzi na wiele pytań dotyczących prowadzenia skutecznej polityki klimatycznej w naszym kraju. Przykładem takiego wkładu jest chociażby zwrócenie uwagi na różnorodność poszczególnych praktyk społecznych, uwikłanie technologii w szerszą ich dynamikę i związaną z tym konieczność odpowiedniego dostosowania interwencji klimatycznych.

Odnośnie do praktycznych implikacji potencjalnych badań warto zauważyć, że o ile przedstawiona literatura koncentruje się na polityce klimatycznej, o tyle dorobek ten może zostać wykorzystany w znacznie szerszym zakresie, na co wskazuje zastosowanie na przykład teorii praktyk społecznych także do badań nad zdrowiem publicznym [Blue, Shove, Carmona, Kelly 2016]. 


\section{BIBLIOGRAFIA}

Berg Holger, Johannes Buhl, Marco Hasselkuß, Till Heller, Silvia Monetti, Karin Stadler, Amelie Mönnikes, Paul Suski, Johannes Thema. 2016. Transition pathways in the making, its scaling up and learning potentials. PATHWAYS project. Exploring transition pathways to sustainable, low carbon societies. Deliverable D3.5. http://www.pathways-project.eu/sites/ default/files/D3_5_Transition\%20pathways\%20in\%20the\%20making_web.pdf [dostęp: 16.12.17].

Bernaciak Magdalena, Aleksandra Lis. 2017. "Weak labour, strong interests: Polish trade unions and the integration of EU energy and service markets. Journal of Common Market Studies 55(3): 432-448.

Bińczyk Ewa. 2013. „Problem sceptycyzmu wobec zmiany klimatycznej a postkonstruktywizm”. Przeglad Kulturoznawczy 1(15): 48-66.

Bińczyk Ewa. 2015. „Monitorowanie technologii a nieusuwalne granice sterowalności (na przykładzie krytyki projektu inżynierii klimatu)". Studia BAS 3(43): 113-136.

Bińczyk Ewa. 2018. Epoka człowieka. Retoryka i marazm antropocenu. Warszawa: Wydawnictwo Naukowe PWN.

Blue Stanley, Elizabeth Shove, Chris Carmona, Michael P. Kelly. 2016. "Theories of practice and public health: Understanding (un)healthy practices". Critical Public Health 26(1): $36-50$.

Brons Anke, Peter Oosterveer. 2017. "Making sense of sustainability: A practice theories approach to bying food". Sustainability 9(3): 1-15.

Browne Alison, Will Medd, Ben Anderson, Martin Pullinger. 2015. Method as intervention. Intervening in practice through quantitative and mixed methodologies. W: Social practices, intervention and sustainability. Beyond behaviour change, Y. Strengers, C. Maller (red.), 179-195. Nowy York: Earthscan from Routledge.

Brulle Robert J., Riley E. Dunlap. 2015. Sociology and global climate change. Introduction. W: Climate change and society. Sociological perspectives, R.E. Dunlap, R.J. Brulle (red.), 1-31. Nowy York: Oxford University Press.

Brzezicka Justyna, Radosław Wiśniewski, Agnieszka Napiórkowska-Baryła. 2016. "Libertarian paternalism and self-government housing policy in Poland". Olsztyn Economic Journal 11(2): 103-118.

Cruz Isabel S., Tally Katz-Gerro. 2016. "Urban public transport companies and strategies to promote sustainable consumption practices". Journal of Cleaner Production 123: 28-33.

Darnton Andrew, Bas Verplanken, Paul White, Lorraine Whitmarsh. 2011. Habits, routines and sustainable lifestyles: A summary report to the Department for Environment, Food and Rural Affairs. Department for Environment, Food and Rural Affairs. http://randd.defra.gov.uk/ Document.aspx?Document=HabitsRoutinesSustainableLifestylesEVO502FinalSummary ReportNov2011(2).pdf [dostęp: 16.12.2017].

Daszyńska-Żygadło Karolina, Bożena Ryszawska. 2015. „Rola społecznej odpowiedzialności przedsiębiorstw w sustainability transition”. Prace Naukowe Uniwersytetu Ekonomicznego we Wroctawiu 395: 62-72.

de Boer Helena, Federico Caprotti. 2017. "Getting Londoners on two wheels: A comparative approach analyzing London's potential pathways to a cycling transition". Sustainable Cities and Society 32: 613-626. 
Ernst Leander, Rutger E. de Graaf-Van Dinther, Gert-Joost Peek, Derk A. Loorbach. 2016. "Sustainable urban transformation and sustainability transitions. Conceptual framework and case study". Journal of Cleaner Production 112: 2988-2999.

Geels Frank W. 2002. "Technological transitions as evolutionary reconfiguration processes: A multi-level perspective and a case-study". Research Policy 31: 1257-1274.

Geels Frank W. 2011. "The multi-level perspective on sustainability transitions: Responses to seven criticism". Environmental Innovation and Societal Transitions 1: 24-40.

Geels Frank W. 2014. "Regime resistance against low-carbon transitions: Introducing politics and power into the multi-level perspective". Theory, Culture and Society 31(5): 21-40.

Geels Frank W., Andy McMeekin, Josephine Mylan, Dale Southerton. 2015. "A critical appraisal of sustainable consumption and production research: The reformist, revolutionary and reconfiguration positions". Global Environmental Change 34: 1-12.

Goszczyński Wojciech, Michal Wróblewski, Anna Wójtewicz. 2018. „Jakość w polskich alternatywnych sieciach żywnościowych. Analiza praktyk społecznych”. Studia Socjologiczne 1(228): 143-170.

Hausknost Daniel, Willi Haas, Sabine Hielscher, Martina Schäfer, Michaela Leitner, Iris Kunze, Sylvia Mandi. 2018. "Investigating patterns of local climate governance: How lowcarbon municipalities and intentional communities intervene in social practices". Environmental Policy and Governance (wersja online przed włączeniem do zeszytu).

Heinrich Andreas, Aleksandra Lis, Heiko Pleines. 2005. Corporate governance in the oil and gas industry: Cases from Poland, Hungary, Russia and Ukraine in a comparative perspective. KICES Working Papers No. 3. SSRN's eLibrary. https://papers.ssrn.com/sol3/papers. cfm?abstract id=2871393 [dostęp: 09.11.2018].

Jackson Tim. 2009. Prosperity without growth. Economics for a finite planet. Londyn, Sterling, Virginia: Earthscan.

Kelsen Hans. 2014. Czysta teoria prawa. Warszawa: LexisNexis.

Klausen Jan E., Katarzyna Szmigiel-Rawska. 2017. "The rabbit and the tortoise. Climate change policy development on the local level in Norway and Poland". Transylvanian Review of Administrative Sciences 52E: 38-58.

Kulawczuk Przemysław, Andrzej Poszewiecki. (red.). 2016. Wplyw oddziaływań behawioralnych na rozwój matych i średnich przedsiębiorstw. Gdańsk: Uniwersytet Gdański Katedra Makroekonomii.

Kundzewicz Zbigniew W., Piotr Matczak. 2012. "Climate change regional review: Poland". WIREs Climate Change 3: 297-311.

Kungl Gregor, Frank W. Geels. 2017. "Sequence and alignment of external pressures in industry destabilization: Understanding the downfall of incumbent utilities in the Germany energy transition (1998-2015)". Environmental Innovation and Societal Transitions 26: 78-100.

Lackowska Marta, Pawel Swianiewicz. 2017. „Czynniki warunkujące preferencje i działania samorządów gminnych w Polsce w zakresie łagodzenia i adaptacji do zmian klimatycznych”. Prace Geograficzne 149: 55-80.

Lackowska Marta, Barbara Nowicka, Marta Balandin, Mirosław Grochowski. 2016. "Lakes sensitivity to climatic stress - a sociological assessment". Miscellanea Geographica - Regional Studies on Development 20(4): 38-47.

Lis Aleksandra. 2011. "Negotiating the European Union emission trading scheme: Re-constructing a calculative space for carbon". Polish Sociological Review 2(174): 77-94. 
Lis Aleksandra, Piotr Stankiewicz. 2017. "Framing shale gas for policy-making in Poland". Journal of Environmental Policy and Planning 19(1): 53-71.

Monreal Alexander C., Andrew McMeekin, Dale Southerton. 2016. "Beyond acquisition: Exploring energy consumption through the appreciation and appropriation of domestic lighting in the UK". Sustainable Production and Consumption 7: 37-48.

OECD. 2017. Behavioural insights and public policy. Lessons from around the world. OECD. http://www.oecd.org/gov/regulatory-policy/behavioural-insights-and-public-policy-9789264270480-en.htm [dostęp: 16.12.2017].

Olejniczak Karol, Pawel Śliwowski. 2014. Nadchodzi rewolucja? Analizy behawioralne w interwencjach publicznych. W: (R)ewaluacja 2. Wiedza w działaniu, A. Haber, K. Olejniczak (red.), 13-45. Warszawa: Polska Agencja Rozwoju Przedsiębiorczości.

Popkiewicz Marcin. 2013. Świat na rozdrożu. Katowice: Sonia Draga.

Popkiewicz Marcin. 2015. Rewolucja energetyczna. Ale po co?. Katowice: Sonia Draga.

Pullinger Martin, Alison Browne, Ben Anderson, Will Medd. (2013). Patterns of water: The water related practices of households in southern England, and their influence on water consumption and demand management. The University of Manchester. https://www.escholar. manchester.ac.uk/uk-ac-man-scw:187780 [dostęp: 27.10.2018].

Rapp Amon, Alessandra Marino, Rossana Simeoni, Federica Cena. 2017. "An ethnographic study of packaging-free purchasing: Designing an interactive system to support sustainable social practices”. Behaviour and Information Technology 36(11): 1193-1217.

Ruszkowski Pawel. 2015. „Problemy polskiej energetyki w perspektywie socjologicznej”. Energetyka-Spoleczeństwo - Polityka 1: 65-87.

Schatzki Theodore. 2015. Practices, governance and sustainability. W: Social practices, intervention and sustainability. Beyond behaviour change, Y. Strengers, C. Maller (red.), 15-30. Nowy York: Earthscan from Routledge.

Shove Elizabeth. 2010. "Beyond the ABC: Climate change policy and theories of social change". Environment and Planning A 42: 1273-1285.

Shove Elizabeth. 2011. "On the difference between chalk and cheese-a response to Whitmarsh et al's comments on 'Beyond the ABC: Climate change policy and theories of social change"'. Environment and Planning 43: 262-264.

Shove Elizabeth. 2017. Practice theory methodologies do not exist. Practice theory methodologies wordpress blog. https://practicetheorymethodologies.wordpress.com/2017/02/15/ elizabeth-shove-practice-theory-methodologies-do-not-exist/ [dostęp: 27.12.2017].

Shove Elizabeth, Mika Pantzar, Matt Watson. 2012. The dynamics of social practice. Everyday life and how it changes. Los Angeles, Londyn, New Delhi, Singapur, Waszyngton DC: SAGE.

Shove Elizabeth, Gordon Walker. 2007. "CAUTION! Transitions ahead: Politics, practice, and sustainable transition management”. Environment and Planning A 39: 763-770.

Smagacz-Poziemska Marta, Andrzej Bukowski, Karol Kurnicki. 2018. «Wspólnota parkingowa». Praktyki parkowania na osiedlach wielkomiejskich i ich strukturalne konsekwencje". Studia Socjologiczne 1(228): 117-142.

Smale Robin, Bas van Vliet, Gert Spaargaren. 2017. "When social practices meet smart grids: Flexibility, grid management, and domestic consumption in The Netherlands". Energy Research and Social Science 34: 132-140. 
Sousa Lourenço Joana, Emanuele Ciriolo, Sara Rafael Almeida, Xavier Troussard. 2016. Behavioural insights applied to policy: European report 2016. Joint Research Centre. http:// publications.jrc.ec.europa.eu/repository/bitstream/JRC100146/kjna27726enn_new.pdf [dostęp: 27.10.2018].

Spurling Nicola, Andrew McMeekin. 2015. Interventions in practices. Sustainable mobility policies in England. W: Social practices, intervention and sustainability. Beyond behaviour change, Y. Strengers, C. Maller (red.), 78-94. Nowy York: Earthscan from Routledge.

Spurling Nicola, Andrew McMeekin, Elizabeth Shove, Dale Southerton, Daniel Welch. 2013. Interventions in practice: Re-framing policy approaches to consumer behaviour. Sustainable Practices Research Group Report. http://www.sprg.ac.uk/uploads/sprg-report-sept-2013.pdf [dostęp: 04.12.2018].

Strengers Yolande, Susie Moloney, Cecily Maller, Ralph Horne. 2015. Beyond behaviour change. Practical applications of social practice theory in behaviour change programmes. W: Social practices, intervention and sustainability. Beyond behaviour change, Y. Strengers, C. Maller (red.), 64-77. Nowy York: Earthscan from Routledge.

Stasik Agata. 2018. „Zastosowanie crowdfundingu we wspieraniu innowacji w dziedzinie zielonej energii: przegląd praktyk oraz diagnoza potencjału i barier”. E-mentor 1(73): 54-62.

Strzałkowski Andrzej. 2016. "Sociology of sociology - strengthening the role of social sciences as a new priority of climate and sustainability policy". Economic and Environmental Studies 16(3): 453-468.

Strzałkowski Andrzej. 2018. "Beyond reductionism - multidisciplinary insights approach for effective climate change and sustainability policy". Economic and Environmental Studies 18(4).

Szmigiel-Rawska Katarzyna. 2017. „Mechanizmy polityki klimatycznej polskich samorządów”. Studia Regionalne i Lokalne 1(67): 48-64.

Upham Paul, Aleksandra Lis, Hauke Riesch, Piotr Stankiewicz. 2015. "Addressing social representations in socio-technical transitions with the case of shale gas". Environmental Innovation and Societal Transitions 16: 120-141.

Wagner Aleksandra. 2015. "Shale gas: Energy innovation in a (non-)knowledge society: a press discourse analysis". Science and Public Policy 42: 273-286.

Wagner Aleksandra (red.). 2016. Widoczne i niewidoczne. Atom, tupki, wiatr w dyskursach medialnych wokót energetyki. Kraków: Wydawnictwo Uniwersytetu Jagiellońskiego.

Warde Alan. 2014. What sort of a practice is eating? W: Sustainable Practices. Social theory and climate change, E. Shove, N. Spurling (red.), 17-30. Abingdon, Oxfordshire, Nowy York: Routledge.

Watson Matt. 2014. Building future systems of velomobility. W: Sustainable practices. Social theory and climate change, E. Shove, N. Spurling (red.), 117-131. Abingdon, Oxfordshire, Nowy York: Routledge.

Watson Matt. 2016. Placing power in practice theory. W: The nexus of practices: connections, constellations, practitioners, A. Hui, T. Schatzki, E. Shove (red.). Londyn: Routledge.

World Bank. 2015. World Development Report 2015: mind, society, and behavior. World Bank. http://documents.worldbank.org/curated/en/645741468339541646/pdf/928630WDR 0978100Box385358B00PUBLIC0.pdf [dostęp: 16.12.2017]. 
Andrzej Strzatkowski

\section{THE IMPLICATIONS OF PRACTICE THEORY, THE MULTI-LEVEL PERSPECTIVE AND BEHAVIOURAL INSIGHTS FOR CLIMATE POLICY}

\section{Summary}

Contemporary political and scientific discourse on climate policy is greatly dominated by the natural sciences, technical sciences and neoclassic economics, and to a lesser degree by psychological behavioural insights. It leads to a significant cognitive gap which more sociological approaches try to fill, e.g., practice theory and the multi-level perspective. In this article, I present the basic assumptions of practice theory, the multi-level perspective and behavioural insights, as well as a way to use these perspectives in parallel in research on climate policy. Moreover, I propose a number of examples of empirical studies from these approaches and indicate potential directions for future research.

Keywords: climate policy, energy policy, environmental sociology, practice theory, multi-level perspective, behavioural insights 